\title{
FIGURATIVE LANGUAGE IN THE STATLER BROTHERS' SELECTED SONG LYRICS FOR LITERATURE TEACHING
}

\author{
Mohammad Ghanaro, Nur Hidayat, Jafar Sodiq \\ Program Studi Pendidikan Bahasa Inggris FPBS Universitas PGRI Semarang \\ Email:moh.ghanaro@gmail.com
}

Submitted: 8 November 2021

Accepted: 11 January 2022

Online Published: 22 January 2022

doi: 10.26418/jeep.v3i1.50339

URL: http://dx.doi.org/10.26418/jeep.v3i1.50339

\begin{abstract}
Figurative language and its meaning is always been a part of literary work. This study aims to identify the types of figurative language used in The Statler Brothers' selected song lyrics, to find the meaning of the figurative language used in the selected song lyrics, and to elaborate the contribution of the study for literature teaching. The research design of this study is qualitative research. In data collection of the study, the writer has analyzed The Statler Brothers' selected songs namely "Bed of Rose's", "New York City", "Flowers on the Wall". "Elizabeth". "Do You Know You Are My Sunshine", "Pictures", and "We Got Paid by Cash". The study results the dominant types of figurative language used in the songs is hyperbole as classified by using Kennedy's theory. The songwriter uses hyperbole to deliver the idea and feeling effectively which is suitable to Kempson's theory. The figurative language in The Statler Brothers' songs can be used as alternative learning material to literature teaching. The writer suggests that the students should learn more about the meaning and the nature of words and sentences. This study is expected to be alternative reference to the next researcher to explain more about figurative language.
\end{abstract}

Keywords: Figurative Language, the Statler Brothers, Lyric, Literature Teaching

To cite this paper (in APA style):

Ghanaro, M., Hidayat, N., Sodiq, J. (2022). Figurative language in the statler brothers' selected song lyrics for literature teaching. Journal of English Education Program, 3(1), 67-75.

\section{INTRODUCTION}

Language is very important for human life. Through language, people can communicate with each other properly. In other words, language can be considered as a tool of communication, for interaction and getting information from one to another. Animals have a communication mechanism with other members of their species due to the nature of language. In addition, humans have a language that can be produced and understood, even the most updated messages, and does not need to be stimulated to understand. Everyone has the ability to learn a language. They learn a language by absorbing the language knowledge in their environment (Kreidler, 2013, p. 3). 
In language learning, meaning can be learned through the branch of linguistics study called semantics. Semantics explains language meanings and the importance of meaning in communication. (Lyons, 1984, p. 183, as cited in Harya, 2016) states that the most widely accepted theory of semantics for a long time is the study of meaning. It constantly talks about ideas or concepts that can be transferred from the speaker's mind to the listener's mind by forming a new language notion that connects them.

As part of the study of meaning, semantics learns the literal and non-literal meaning. The literal meaning is the denotative words that have natural meaning or do not have any other meaning as it is written, or it can be called literal meaning. On the other hand, non-literal meaning is the words that have implicit or hidden meanings and can be interpreted in multiple understandings.

English, which is the global language spoken throughout the world, can be learnt through education. In Indonesia, there are two ways to learn English through education. First, people can learn English in formal education by school or academy, which offers a larger selection of English learning materials. On the other side, people can also learn English through non-formal education by taking courses. For instance, they learn English in private English courses, where they learn English with only one purpose, which is communicative purpose. People who take English courses usually learn English only for practical needs. Those are the ways how people learn English through education.

English language teaching is not only about grammar, speaking, writing, listening, reading, etc. It can be also about literature teaching. The study of literature is important because it can help students see the world - people, places, things, events - through different eyes and by way of a different point of view. It also enables individuals to solve difficulties and figure out what is true. Reading literature is an excellent way to improve critical thinking abilities. A reader must pay attention to details, draw connections, and establish their own conclusions about what is happening in the literary works. Literature is commonly used by teachers to help pupils develop excellent critical thinking skills.

Teachers employ some tools based on literary art in order to pique students' interest in learning English literature. Prose, theater, books, movies, music, and songs are examples of literary arts that can be linked to modern learning through media. Literature is a linguistic art. according to Aditya \& Puspani, 2017, p. 19, it denotes the creation of a literary work with the intention of entertaining the reader or listener. To put it another way, literary works contain personal expression based on emotion, concept, experience, or even the author's own imagination. Plays, books, and poetry can all be examples of literary works.

Poetry is a type of short writing that is considered literature. It is used to convey emotion, thought, feeling, and so on. However, in order to write poetry, the author must understand how to use figurative language correctly. According to Harya, 2016, p. 46, figurative language is the use of words and expressions that have a different meaning than literal implication. Figurative language can be used to express the speaker's ideas and feelings in any communication, but it is rarely used in everyday conversation. Listeners 
should use their imaginations to understand the use of figurative language. For example, if the sentence "The grass is dancing after the wind whispers to them" is interpreted using denotative, also known as cognitive meaning, the sentence implies something nonsense. Otherwise, if readers use their imagination, they will create a different meaning, such as "the breeze softly touches the grass, and the grass is waving like dancing people."

On the other hand, Perrine, 1982, p. 10, in Harya, 2016 mentions that there are four main reasons to use figurative language. First, figurative language can give imaginative pleasure to the reader. Second, it can be said that it will bring additional imagery to its verse, making the literary works become more sensuous and the abstract become concrete. Third, figurative language is a way of adding emotional intensity to informative statements and conveying attitudes along with the information. The last is the way to say much in a brief compass.

Song, as one of the literary works which is the branch creation of poetry, is an expression from the composer that is poured into paper containing words or lyrics and is accompanied by some musical instruments (Sadiasih \& Dewi, 2016). The music and song are attracted to each other, so the combination of music and song will beautify the lyrics of the listener's lyrics.

Unfortunately, there is no conducted related study in which the analysis of The Statler Brothers' songs. Therefore, the writer decides to conduct the study and chooses The Statler Brothers' songs because there are no researchers who have conducted a study about figurative language in old music, regarding that music is considered long-lasting literary works and still relevant as long as it has a lot of listeners.

To sum up, the writer decides to be the first who analyze The Statler Brothers' songs. Hence, this study is conducted to identify the types of figurative language used in The Statler Brothers' songs and to elaborate on its contribution to English literature teaching.

\section{RESEARCH METHOD}

The method used in this study is the descriptive qualitative method. Moleong, 2011, p. 11, as cited in Listiani, 2015 states the implementation of the descriptive qualitative approach does not deal with the arithmetic calculation details, statistics, or object description.

The goal of the descriptive qualitative method is to describe a place, its characteristics, and the facts about the population in a systematic, factual, and accurate way. The descriptive qualitative method involves a technique of seeking, collecting, and analyzing data. Qualitative research uses content analysis, which involves not only analyzing the textual context but also creating the context. The data can be analyzed by paying special attention to what the created context is, identifying the themes, and obtaining a meaningful interpretation of the data (Roller \& Lavrakas, 2015, in Leavy, 2017, p. 146).

\section{The Data of the Study}

The source of data is the selected song lyrics by The Statler Brothers. The writer decided to choose certain songs because they have reached their best performance in Hot Country Music Billboard and those are well-known songs since their first performance. The songs are written based on a romantic story and cultural aspects in America back in the 1970s. 
The titles of the songs are Bed of Rose's, New York City, Flowers on the Wall, Elizabeth, Do You Know You Are My Sunshine, Pictures, and We Got Paid by Cash.

\section{The technique of Data Collection}

This study uses library research and document study to collect the relevant data. (1) Library research is used to search the data through the internet. The writer also looks for the literature teaching, figurative language, The Statler Brothers, the theory of meaning and message, music and song, and song lyrics through the books, journals, and relevant literature. (2) Document Study. Patton, 2002; Raco, 2010, p. 110 provides that there are three kinds of qualitative data. They are deep interviews, observation, and documents. The document is written material that is recorded. The document is also can be memorabilia or note or correspondence. To keep the record of the collected document, the document study method will be used in this study.

\section{Data Analysis}

This study uses the steps of analyzing qualitative data adopted by Creswell and Poth (2016). Usually analyzing the qualitative data is not simple. Patton, 2002, as cited in Cohen et al., (2018), p. 643 remarks that the qualitative data analysis does not have a simple formula nor does it has its measuring instrument to perceive its validity and credibility. The activities of data analysis that will be used are: (1) Data reduction is a process of selecting words that use certain figurative language. In order to analyze the figurative language that used in selected song lyrics, the writer will select the words that have figurative language and find the meaning and the message. (2) Data display is an organized collection of information that allows drawing and action-taking. After the data is analyzed from the lyrics, the writer will display the result of the analysis in descriptive form according to each figurative language used. (3) Drawing a conclusion is the last activity after analyzing the data. The final conclusion will not appear until the data collection is over. So that the writer will finish the data collection first, then the writer will draw the final conclusion.

\section{RESULT AND DISCUSSION \\ Research Findings}

The objective of this study is to identify the types of figurative language used in The Statler Brothers' selected song lyrics and to elaborate on the contribution of this research to English literature teaching.

In this research, the writer has analyzed seven of The Statler Brothers' songs. They are Bed of Rose's, New York City, Flowers on the Wall, Elizabeth, Do You Know You Are My Sunshine, Pictures, and We Got Paid by Cash. The purpose of using the selected songs as the source data is the songs use many types of figurative language and each of them contains the meaning which needs to be analyzed in order to understand the implicit meaning and message from the lyrics.

Kennedy \& Dana, 2013 classify the type of figurative language into eight, namely Simile, Metaphor, Synecdoche, Metonymy, Paradox, Personification, Hyperbole, and Oxymoron. Based on the classification, the writer finds out from seven song lyrics in The Statler 
Brothers' selected songs, there are seven types of figurative language indicated by 30 items. The data is presented in the table below.

Table 1. Figurative Language in The Statler Brothers' songs

\begin{tabular}{|c|c|c|c|c|c|c|c|c|}
\hline No & Song & $\underset{\text { e }}{\text { Simil }}$ & Metaphor & Metonymy & Paradox & Personification & Hyperbole & Oxymoron \\
\hline 1 & $\begin{array}{l}\text { Bed of } \\
\text { Rose's }\end{array}$ & 1 & - & 1 & - & - & 1 & 1 \\
\hline 2 & $\begin{array}{c}\text { New York } \\
\text { City }\end{array}$ & 1 & - & - & 1 & - & - & 1 \\
\hline 3 & $\begin{array}{l}\text { Flowers on } \\
\text { the Wall }\end{array}$ & 1 & 1 & 1 & - & 2 & - & - \\
\hline 4 & Elizabeth & - & - & - & - & - & 5 & - \\
\hline 5 & $\begin{array}{c}\text { Do You } \\
\text { Know You } \\
\text { Are My } \\
\text { Sunshine }\end{array}$ & 2 & - & 1 & - & - & 2 & - \\
\hline 6 & Picture & 1 & - & - & - & - & 3 & - \\
\hline 7 & $\begin{array}{c}\text { We Got Paid } \\
\text { by Cash }\end{array}$ & - & - & 2 & 2 & - & - & - \\
\hline & TOTAL & 6 & 1 & 5 & 3 & 2 & 11 & 2 \\
\hline
\end{tabular}

From the table above, the writer finds some lyrics which contain figurative language in every song. The total of figurative language finds in The Statler Brothers' selected song lyrics was thirty items in total. They are six similes, a metaphor, five metonymies, three paradoxes, two personifications, eleven hyperboles, and two oxymorons.

In the first song entitled "Bed of Rose's", the writer finds four items of figurative language, there are an Oxymoron, a Metonymy, a Simile, and a Hyperbole. In the second song entitled "New York City", the writer finds three items of figurative language, there are a Simile, a Paradox, and an Oxymoron. In the third song entitled "Flowers on The Wall", the writer finds five items of figurative language, there are a Metonymy, a Simile, a Metaphor, and two Personifications. In the fourth song entitled "Elizabeth", the writer finds five items of figurative language, those of figurative language used in this song are Hyperbole. In the fifth song entitled "Do You Know You Are My Sunshine", the writer finds five items of figurative language, they are a Metonymy, two Similes, and two Hyperboles. In the sixth song entitled "Pictures", the writer finds four items of figurative language, there are three Hyperboles and one Simile. In the seventh song entitled "We Got Paid by Cash", the writer finds four items of figurative language namely two Paradoxes and two Metonymy.

In order to know the most figurative language used in The Statlers Brothers' songs, the writer makes a pie chart to provide the percentage of the figurative language used in the song lyrics. 


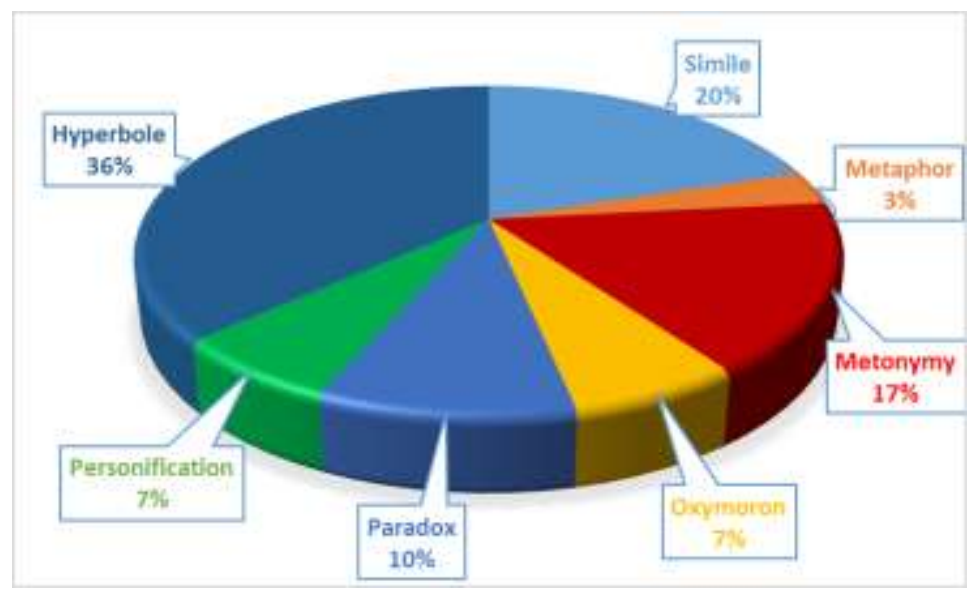

Figure 1. Figurative Language in The Statler Brothers' songs

From the chart above, we can see the result of the types of figurative language used in seven selected songs in percentage. The writer finds seven types of figurative language. The most used figurative language in The Statler Brothers' selected song lyrics is Hyperbole with $36 \%$. Then the following dominant figurative language used in the song lyrics are Simile with $20 \%$ and Metonymy with $17 \%$, then followed by Paradox with $10 \%$, Oxymoron 7\%, Personification 7\%, and Metaphor 3\%.

\section{DISCUSSION}

The writer analyzes seven of The Statler Brothers' songs, namely Bed of Rose's, New York City, Flowers on the Wall, Elizabeth, Do You Know You Are My Sunshine, Pictures, and We Got Paid by Cash. In figurative language analysis, the writer uses Kennedy's theory. Kennedy (2013) classifies figurative language into eight types. Those are Simile, Metaphor, Synecdoche, Metonymy, Paradox, Personification, Hyperbole, and Oxymoron. In addition, the writer also uses Kempson's theory to support the classification of the types of figurative language used in The Statler Brothers' song lyrics Kempson, 1977, in Kreidler, 2013, states there are three main ways to construct a meaning in natural language, namely defining the word meaning, defining the nature of the sentence, and explaining the process of communication.

The result from the data analysis, The Statler Brothers' songs mostly contain hyperbole to imply the songwriter's message and feeling because it is suitable to use in recent days, especially in romantic and swear words. The writer finds out that the songwriter puts hyperbole into the song lyrics because it is effective than using the other figurative language. The examples of hyperbole are mostly found in The Statler Brothers' song entitled "Elizabeth". For instance. The lyrics "Don't know if I could ever live my life without you" the lyricist included hyperbole. The lyricist wants to express if he cannot continue living without someone loved. It becomes dramatizing situation because in real life a person can continue living without someone he/she loved. The true meaning of these lyrics is if the man is afraid of losing his beloved wife, and he does not know how to continue his life without his wife. In addition to this, the lyric "You gave me strength and love with life that felt brand new" is also contained with hyperbole. The hyperbole is underlined by the phrase "brand new". In accordance with Cambridge Dictionary, it means an unused thing or completely fresh. The true meaning of this lyric is the man's wife has filled his life with strength and love that refreshes him every time felt like a new thing. 
Furthermore, in the song entitled "Do You Know, You Are My Sunshine" is also found hyperbole by two items. In lyrics "Do you know, 'You Are My Sunshine?" uses hyperbole. The lyricist put hyperbole into "You Are My Sunshine". Sunshine means light from the sun which has advantages and disadvantages to human life. Implicitly, the meaning of this lyric is someone becomes the light for the other. The other findings according to hyperbole is in the lyric "Do you know what your smile did to $m e$ ". The lyricist implied a question to someone who smiled at him. Connotatively, the lyricist wants to tell a woman that he was so happy since the woman gave her smile to him directly.

These results are different from Harya's study (2016). In Harya's study, he uses Leech's theory to identify the types of figurative language in Coelho's Novel Entitled "Alchemist". In his study, he finds 70 sentences are contained with figurative language. Form all sentences, he found 30 items of simile, 27 items of personification, 12 items of metaphor, and 1 item of hyperbole. On the other hand, Wibisono et al., 2019 conduct a study to analyze the figurative language in Online Short Story Posted on The Jakarta Post. The study uses Perrine's theory. This study has resulted in the types of figurative languages found in the short story are simile, personification, hyperbole, metaphor, irony, and metonymy. Moreover, a different study is conducted by Nuraeni \& Peron (2017) in which they are analyzing the figurative language types in Kelly Darrow's selected poetry. They use Mckenzie's theory to identify the types of figurative language. The study results that the types of figurative language used in simile, metaphor, personification, hyperbole, understatement, and irony.

Based on the previous studies, it can be seen if this study has differences and similarities. In Harya's study, the most figurative language found in the literary work are simile by 40 items found in the Alchemist novel. This study is in contrast with Harya's. In this study, hyperbole is dominant than simile and presented by 11 items. Moreover, the similarity can be identified in Wibisono and Widodo, and Nuraeni and Peron to this study are also found the types of figurative language, namely simile, metaphor, personification, metonymy, and hyperbole.

The whole presented findings lead to its contribution to English literature teaching. The findings of the study can be the learning source for readers and students, who are interested to learn literature, especially in English literature. The student may use the result of the study to be references to analyze figurative language and its meaning. The teacher or lecturer may use the result to be additional references to teach literature. Otherwise, the students usually associate literary works such as song lyrics to their real-life by seeking certain topics through popular music or their favorite music (Clark, 2011). So that, this study contributes to adding information in teaching poetry and song. Also, the reader can use the result as additional information to enrich the meaning and knowledge, especially in finding figurative languages in literary works.

\section{CONCLUSION AND SUGGESTION}

The writer finds seven types of figurative language. The most used figurative language in The Statler Brothers' selected song lyrics is Hyperbole with $36 \%$. Then the following dominant figurative language used in the song lyrics are Simile with $20 \%$ and Metonymy with $17 \%$, then followed by Paradox with $10 \%$, Oxymoron $7 \%$, Personification $7 \%$, and Metaphor 3\%. The Statler Brothers' songs mostly use hyperbole than the other types of 
figurative language. It implies that the songwriter produces the songs by using hyperbole to express the idea and feeling effective than using plain language. The Statler Brothers' songs mostly contain implicit meaning. It is suitable to Kempson's theory which interprets the meaning by selecting certain words or sentences to find the implicit meaning. The figurative languages realized in The Statler Brother's song lyrics can be used as the reference or alternative source learning to literature teaching. Based on the conclusion above, this study is expected to give a worthy contribution for the teacher to teach literature studies by using songs as media. This media is interesting to increase the students' skills. The researcher expects this study enriches the students' knowledge, especially about figurative language. The result of this study is hopefully can be used as a source or reference in conducting further studies about figurative language with other media or objects of study. In addition, this study can help and become an alternative reference to the next researcher to explain more about figurative language. The students should learn more about figurative language. The students need to take deeper knowledge in the language. The students must use their knowledge absolutely and share their knowledge with others. So, to get the best result, the students must improve their ability in learning.

\section{REFERENCES}

Aditya, N. T., \& Puspani, I. A. M. (2017). The Analysis of Figurative Language in Linkin Park's Song Lyrics. Jurnal Humanis, Fakultas Ilmu Budaya Unud, 21(1), 19-23.

Clark, C. (2011). Why teach Poetry. Education Publishing Services.

Cohen, L., Manion, L., \& Morrison, K. (2018). Research Methods in Education 8th Edition (8th ed.). Routledge. https:/ / doi.org/https://doi.org/10.4324/9780203224342

Creswell, J. W., \& Poth, C. N. (2016). Qualitative Inquiry and Research Design: Choosing among Five Approaches. SAGE Publications.

Dewi, L. A. (2020). Figurative Language in Maher Zain's Song Lyrics [IAIN Ponorogo]. http://etheses.iainponorogo.ac.id/id/eprint/10310

Harya, T. D. (2016). An Analysis of Figurative Languages Used in Coelhos'S Novel Entitled "Alchemist." PREMISE JOURNAL:ISSN Online: 2442-482x, ISSN Printed: 2089-3345, 5(2), 46. https:/ / doi.org/10.24127/pj.v5i2.815

Kempson, M. R. (1977). Semantic Theory. Cambridge University Press. https:/ / doi.org/10.2307/2219194

Kennedy, X., \& Dana, G. (2013). Literature: A Introduction to Fiction, Poetry, Drama, and Writing. Pearson.

Kreidler, C. (2013). Introducing English Semantics. Routledge. https:/ / doi.org/10.4324/9781315886428

Leavy, P. (2017). Research Design: Quantitative, Qualitative, Mixed Methods, Arts-Based, and Community-Based Participatory Research Approaches. The Guilford Press. https:/ / doi.org/10.1088/1751-8113/44/8/085201

Listiani, H. (2015). An Analysis of Figurative Language Found on The Song Lyric by Taylor Swift's “Speak Now" Album. State Institute for Islamic Studies Salatiga, 144. http:/ / e-repository.perpus.iainsalatiga.ac.id

Lyons, J. (1984). Language and Linguistics. Cambridge University Press.

Moleong, L. J. (2011). Metodologi Penelitian Kualtitatif. PT REMAJA ROSDAKARYA. https://ecampus.unusia.ac.id/repo/handle/123456789/9782?show=full

Nuraeni, C., \& Peron, P. A. (2017). Figurative Language In Kelly Darrow's Selected Poetry. 
Wanasastra, IX(2), 122-129. https:// doi.org/https:/ / doi.org/10.31294/w.v9i2.2480 Patton, M. Q. (2002). Two Decades of Developments in Qualitative Inquiry: A Personal, Experiential Perspective. Sage Journals. https://doi.org/doi.org/10.1177/1473325002001003636

Panyasi, S. (2015). Teaching English literature to English as a Second Languages. In Doctoral Thesis. https:/ /opus.cloud.lib.edu.au/handle/10453/39192

Perrine, L. (1982). An Introduction to Poetry. In Southern Methodist University (Third). Harcourt, Brace, \& World, INC. https:// doi.org/10.2307/806087

Raco, J. R. (2010). METODE PENELITIAN KUALTITATIF. PT Grasindo. http://eprints.mercubuana-yogya.ac.id/id/eprint/388

Reaske, C. R. (1966). How to Analyze Poetry. MacMillan Publishing Company.

Roller, M. R., \& Lavrakas, P. J. (2015). Applied qualitative research design: A total quality framework approach. Guilford Publications. https://doi.org/https://doi.org/10.1037/qup0000081

Sadiasih, N. K. P. M., \& Dewi, P. C. (2016). FIGURATIVE LANGUAGE IN SONG LYRICS BY RIHANNA AND KATY PERRY. Litera Journal Bahasa Dan Sastra, 2(2), 93-97. https://jurnal.undhirabali.ac.id/index.php/litera/article/view/196

Wibisono, T., Widodo, P., \& Info, A. (2019). An Analysis of Figurative Language in Online Short Story Posted on The Jakarta Post. Prasasti: Journal of Linguistics, 4(2), 156-165. https://doi.org/dx.doi.org/10.31604/linguistik.v4i2.62-72 